\title{
Serum C-reactive protein level does not correlate with Crohn's Disease Activity Index
}

\author{
Stężenie białka C-reaktywnego nie koreluje ze wskaźnikiem aktywności choroby \\ Leśniowskiego-Crohna
}

\author{
Maciej Kohut, Katarzyna Kozioł*, Emilia Olek*, Anna Koclęga*, Marek Hartleb \\ Department of Gastroenterology and Hepatology, Medical University of Silesia, Katowice, Poland \\ *Students organized in scientific Students Circle at the Department of Gastroenterology and Hepatology, Medical University \\ of Silesia, Katowice, Poland
}

Przegląd Gastroenterologiczny 2010; 5 (5): 274-278

DOI: $10.5114 /$ pg.2010.17264

Key words: Crohn's disease, C-reactive protein, disease activity.

Słowa kluczowe: choroba Leśniowskiego-Crohna, białko C-reaktywne, aktywność choroby.

Address for correspondence: Maciej Kohut, MD, PhD, Department of Gastroenterology and Hepatology, Medical University of Silesia, ul. Medyków 14, 40-752 Katowice, Poland, phone +48 3278944 01, e-mail: kohutm66@wp.pl

\begin{abstract}
Introduction: Crohn's Disease Activity Index (CDAl) is a conventional, but poorly validated estimate of severity of Crohn's disease (CD). Similarly, the clinical significance of elevated levels of C-reactive protein (CRP) in CD patients is not well recognized. It is also unknown whether these two indices have similar informative value.

Aim: To investigate the correlation between serum CRP level and CDAl.

Material and methods: One hundred and forty-six patients (66 men and 80 women, mean age $37 \pm 12$ years) with well established diagnosis of $C D$ were included in the study. According to the admittance protocol in all patients the serum CRP was measured and all data necessary to calculate CDAI were collected.

Results: There was no significant correlation between CRP and CDAl either in the entire population or in subgroups selected on the basis of CD severity, site of bowel involvement, kind of ongoing pharmacological therapy, past surgery or body mass.

Conclusions: There is no correlation between serum CRP level and CDAI. These two indices reflect different aspects of CD severity.
\end{abstract}

\section{Introduction}

The natural course of Crohn's disease (CD) is characterized by periods of exacerbations and remissions. The exacerbations are life-threatening events which usually come unpredictably and could be prevented if early

\section{Streszczenie}

Wstęp: Wskaźnik aktywności choroby Leśniowskiego-Crohna (Crohn's Disease Activity Index - CDAI) to typowy, ale niedostatecznie standaryzowany sposób szacowania ciężkości tej choroby. Również kliniczne znaczenie zwiększonego stężenia osoczowego białka C-reaktywnego (CRP) nie zostało ostatecznie ustalone w tej chorobie. Nie jest pewne, czy dwa wymienione wskaźniki niosą podobną informację kliniczną.

Cel: Zbadanie korelacji między stężeniem osoczowego CRP i wartością CDAl.

Materiał i metody: Stu czterdziestu sześciu kolejnych chorych (66 mężczyzn i 80 kobiet, średni wiek $37 \pm 12$ lat) z pewnie ustalonym rozpoznaniem choroby Leśniowskiego-Crohna zostało włączonych do badania. Posługując się wcześniej ustalonym prokołem badania, u wszystkich chorych oznaczno przy przyjęciu stężenie osoczowe CRP i zebrano wszystkie niezbędne dane do obliczenia wskaźnika CDAI.

Wyniki: Nie stwierdzono istotnej statystycznie korelacji między stężeniem CRP i CDAl zarówno w całej badanej kohorcie, jak i w podgrupach wydzielonych na podstawie ciężkości choroby, lokalizacji choroby, stosowanego obecnie leczenia farmakologicznego, uprzedniego leczenia chirurgicznego oraz masy ciała. Wnioski: Nie stwierdzono korelacji między osoczowym stężeniem CRP a wartością CDAl. Badane wskaźniki odzwierciedlają różne aspekty ciężkości choroby Leśniowskiego-Crohna.

stages of flares were discovered by a non-invasive test. Therefore, it is of great importance to find a reliable indicator of existing mucosal inflammatory activity [1].

Crohn's disease is associated with impairment of the bowel mucosal barrier and profound dysfunction of the 
immunological system reflected by increased activity of T lymphocytes (mostly the Th1 subpopulation). Activated Th1 cells are the source of pro-inflammatory cytokines, such as IL-6, that stimulate hepatic synthesis of C-reactive protein (CRP) [2, 3]. CRP was first described in 1930 by Tillet and Francis [4], who identified this substance in the serum of a patient infected with pneumococcal pneumonia CRP was subsequently considered an "acute phase protein" playing an important diagnostic role in infectious and inflammatory conditions. Moreover, it has been shown that CRP is unaffected by most medications [5].

Many studies have demonstrated elevated CRP levels in patients with active CD [6-9]. It was suggested that CRP may better reflect the surface of active mucosal inflammation in CD than in ulcerative colitis [7-11]. However, a recently published study denied any correlation between CRP level and endoscopically assessed mucosal status in CD patients [12]. There is also no consensus on the role of CRP measurement in prediction of exacerbations in inflammatory bowel disease (IBD) [13].

Crohn's Disease Activity Index (CDAI) is a numerical calculation of 8 clinical variables selected empirically and multiplied by weighting factors derived from multivariate analysis (tab. I). CDAl was developed for the National Cooperative Crohn's Disease Study to objectively assess response to therapy among patients managed at many participating centres [14]. CDAl score below 150 indicates disease remission, of 150-219 denotes mild active disease, of 220-450 means moderately active disease, and above 450 signifies a severe flare $[14,15]$. The CDAl has been criticized as a measure of illness rather than disease activity. Generally, the vari-

Table I. Crohn's Disease Activity Index

(Best 1976)

Tabela I. Wskaźnik aktywności choroby

Leśniowskiego-Crohna (wg Best 1976)

\begin{tabular}{llc} 
No. & Factor & Multiplication \\
\hline 1 & $\begin{array}{l}\text { Number of liquid or very soft stools } \\
\text { in the last week }\end{array}$ & $\times 2$ \\
\hline 2 & Abdominal pain score in the last week & $\times 5$ \\
\hline 3 & General well-being in the last week & $\times 7$ \\
\hline 4 & $\begin{array}{l}\text { 6 extra-intestinal symptoms or findings } \\
\text { presumably related to Crohn's disease }\end{array}$ & $\times 20$ \\
\hline 5 & Treatment with anti-diarrhoeal drugs & $\times 30$ \\
\hline 6 & Abdominal mass on physical exam & $\times 10$ \\
\hline 7 & Haematocrit (ideal - actual) & $\times 6$ \\
\hline 8 & $100 \times(1-[$ body weight/standard weight]) & $\times 1$ \\
\hline & Total CDAl & $\ldots$
\end{tabular}

ables entered into CDAl lack specificity and their assessment may be easily influenced by subjective interpretation of both the patient and the gastroenterologist [14, 15]. Though imperfect, the CDAI remains the most commonly used index of severity of CD.

Taken together, the clinical significance of CDAl or CRP for estimation of the extent and activity of mucosal involvement in different stages of CD is not well established. This issue is becoming especially important in view of newly emerging tests, such as faecal measurements of calprotectin or lactoferrin $[16,17]$. It is also unknown whether CDAI and CRP carry similar information on activity of CD. The aim of this study was to investigate in a large group of patients with CD the relationship between serum CRP level and disease activity measured by CDAl, taking into account clinical characteristics of these patients.

\section{Material and methods}

One hundred and forty-six consecutive patients (66 men, 80 women) in whom a diagnosis of CD was unequivocally established on the basis of clinical, radiological, endoscopic and histological criteria were prospectively included in the study, irrespective of disease activity. All patients were hospitalized in the Department of Gastroenterology and Hepatology of the Silesian Medical University in Katowice between February, 2005 and November, 2007. Demographic characteristics of patients are shown in table II.

In all patients the disease activity was determined by CDAI. The CDAl and CRP were determined at the same time according to the admittance protocol. The CRP levels were measured using a turbidimetric immunoassay.

The correlation between CRP and CDAI was calculated by Pearson's correlation test (Excel Microsoft, 2003).

Table II. Demographic and clinical characteristics of 146 patients

Tabela II. Charakterystyka demograficzna i kliniczna 146 chorych

\begin{tabular}{lc} 
Variable & Result \\
\hline Men : women & $66: 80(45 \%: 55 \%)$ \\
\hline Age [years] & 37 (range 19-80) \\
\hline Duration of disease [years] & 6.23 (range 0.25-50) \\
\hline CD limited to the small bowel, $n(\%)$ & $12(8.22)$ \\
\hline lleo-colonic disease, $n(\%)$ & $120(82.19)$ \\
\hline Crohn's colitis, $n(\%)$ & $14(9.59)$ \\
\hline External fistulas, $n(\%)$ & $55(38)$ \\
\hline Past resective surgery, $n(\%)$ & $60(41)$ \\
\hline Appendectomy, $n(\%)$ & $27(18.5)$
\end{tabular}




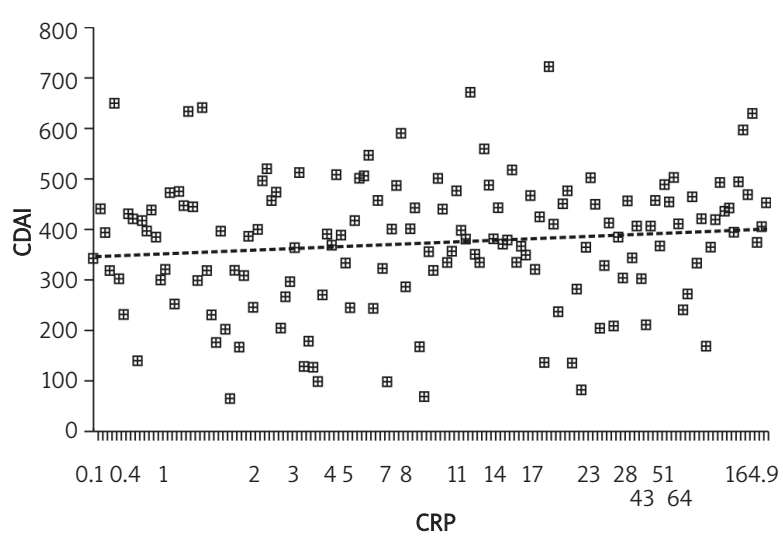

Pearson's correlation coefficient $r=0.184$

Fig. 1. Overall correlation between CRP and CDAI Ryc. 1. Ogólna korelacja między CRP i CDAI

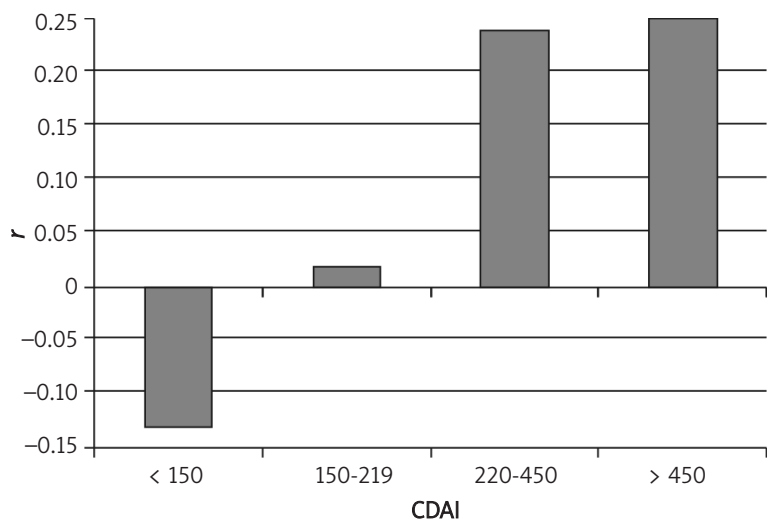

Fig. 2. Correlation coefficients $(r)$ between CRP and different CDAl score ranges

Ryc. 2. Wspótczynnik korelacji (r) między CRP i CDAl w różnych przedziałach wartości CDAl

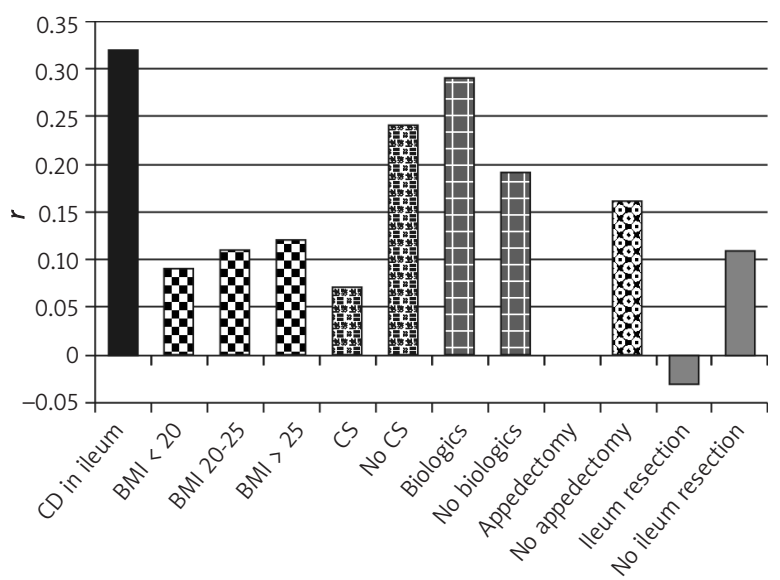

$C D$ - Crohn disease, $B M I$ - body mass index, CS - corticosteroids

Fig. 3. Correlation coefficients $(r)$ between CRP and CDAI in different clinical subgroups

Ryc. 3. Wspótczynnik korelacji (r) pomiędzy CRP i CDAl w różnych podgrupach chorych
A $p$ value of $<0.05$ was considered as significant. We also calculated correlations between CDAI and CRP in the following subgroups of CD patients with:

- CDAl < 150, 150-219, 220-450, > 450 points,

- disease involving exclusively the ileocaecal region vs. other locations,

- body mass index $(\mathrm{BMI})<20,20-25$ and $>25 \mathrm{~kg} / \mathrm{m}^{2}$,

- ongoing treatment with corticosteroids,

- ongoing biological treatment (infliximab or adalimumab),

- previous appendectomy,

- previous bowel resective surgery.

\section{Results}

The median CDAl score of all patients was 388 points (range 65-621). Non-active or mild form of CD was diagnosed in 20 patients $(\mathrm{CDAl} \leq 220)$ and moderately or highly active disease in 126 patients (CDAl $>220$ ). Serum CRP level above the upper limit of the normal range $(5 \mathrm{mg} / \mathrm{l})$ was found in 91 patients. The median CRP level was $8.7 \mathrm{mg} / \mathrm{l}$ (range 0.1-220 mg/l). Overall CRP and CDAI Pearson's correlation factor was 0.184. Detailed results of correlations between CRP and CDAl in subgroups of CD patients are summarised in figures 1-3.

\section{Discussion}

The measurement of inflammatory activity in $C D$ is important not only in clinical trials but also in the setting of everyday practice to predict the course of the disease and to monitor effects of treatment [10, 18, 19]. An ideal biomarker should be disease specific, easy to perform, non- or minimally invasive, and providing rapid and reproducible results. Endoscopic or radiological methods fulfil only in part the above targets.

Measurement of serum CRP level was proposed to differentiate between intestine inflammation and functional disorders $[16,17]$. An increased interest in CRP as a marker of inflammation in CD is derived from clinical trials evaluating effects of biological agents. In patients treated with infliximab, a pre-therapeutic CRP level more than $5 \mathrm{mg} / \mathrm{l}$ was associated with $76 \%$ positive therapy response compared with only $46 \%$ found in patients with baseline CRP level lower than $5 \mathrm{mg} / \mathrm{l}$. Similar results have been demonstrated with the use of adalimumab and anti-adhesion molecules [20-22].

Recent studies have suggested that polymorphisms in the CRP gene, located on the long arm of chromosome 1 (1q23-24), account for inter-individual differences in CRP synthesis in humans [23-25]. However, data on the effect of CRP gene polymorphisms on the level of this peptide in IBD patients provide no clear 
message. A recent study investigating CRP polymorphisms in IBD patients showed no apparent association with serum CRP levels [26].

In the study of Karoui et al. the correlation coefficient between CRP and CDAl, although statistically significant, was only 0.3 [6]. Our study shows an even less significant correlation between serum CRP levels and CDAI. This finding holds true not only for the whole investigated population of patients with $C D$, but also for subpopulations selected on the basis of disease activity, intestinal location of inflammation, administered medications, past surgery and body mass index. A weak correlation was found in $C D$ patients showing exclusive involvement of the terminal ileum.

Mucosal healing is the best prognostic factor with respect to such outcomes as need for hospitalisation (including costly ICU treatment) and for surgery [27]. In common opinion CRP may be a more appropriate indicator of mucosal status than CDAI [2, 28-30].

\section{Conclusions}

There is no correlation between serum CRP level and CDAl. The clinical significance of both indices should be further investigated as they seem to reflect different aspects of CD-related pathology.

\section{References}

1. Nielsen $\mathrm{OH}$, Ben Vainer MD, Soeren MM, et al. Established and emerging biological activity markers of inflammatory bowel disease. Am J Gastroenterol 2000; 95: 359-67.

2. Filik L, Dagli U, Ulker A. C-reactive protein and monitoring the activity of Crohn's disease. Adv Ther 2006; 23: 655-62.

3. Nancey S, Hamzaoui N, Moussata D, et al. Serum interleukin6, soluble interleukin-6 receptor and Crohn's disease activity. Dig Dis Sci 2008; 53: 242.

4. Tillett WS, Francis Jr T. Serological reactions in pneumonia with a nonprotein somatic fraction of pneumococcus. J Exp Med 1930; 52: 561-85.

5. Gisbert JP, Gonzales-Lama Y, Mate J. Role of biological markers in inflammatory bowel disease. Gastroenterol Hepatol 2007; 30: $117-29$.

6. Karoui S, Ouerdiane S, Serghini M, et al. Correlation between levels of C-reactive protein and clinical activity in Crohn's disease. Dig Liver Dis 2007; 39: 1006-10.

7. Andre C, Descos L, Landais P, et al. Assessment of appropriate laboratory measurements to supplement of Crohn's disease activity index. Gut 1981; 22: 571-4.

8. Fagan EA, Dyck RF, Maton PN, et al. Serum levels of C-raective protein in Crohn's disease and ulcerative colitis. Eur J Clin Invest 1982; 12: 351-60.

9. Sachar DB, Luppescu NE, Bodian C, et al. Erythrocyte sedimentation as a measure of Crohn's dieses activity: opposite trends in ileitis versus colitis. J Clin Gastroenterol 1990; 12: 643-6.

10. Louis E, Vermeire $S$, Rutgeerts $P$, et al. A positive response to infliximab in Crohn disease: association with a higher systemic inflammation before treatment but not with -308 TNF gene polymorphism. Scand J Gastroenterol 2002; 37: 818-24.

11. Rodgers AD, Cummins AG. CRP correlates with clinical score in ulcerative colitis but not in Crohn's disease. Dig Dis Sci 2007; 52: 2063.

12. Jones J, Loftus EV Jr, Pannacione R, et al. Relationship between disease activity and serum and fecal biomarkers in patents with Crohn's disease. Clin Gastroenterol Hepatol 2008; 6: 1218-24.

13. Denis MA, Reenaers C, Fontaine F, et al. Assessment of endoscopic activity index and biological inflammatory markers in clinically active Crohn's disease with normal C-reactive protein serum level. Inflamm Bowel Dis 2007; 13: 1100-5.

14. Best WR, Becktel JM, Singleton JW. Rederived values of the eight coefficients of the Crohn's Disease Activity Index (CDAI). Gastroenterology 1979; 77: 843-6.

15. Best WR, Becktel JM, Singleton JW, Kern Jr. Deelopment of a Crohn's disease activity index. National Cooperative Crohn's Disease Study (NCCDS). Gastroenterology 1976; 70: 439-44.

16. Langhorst J, Elsenbruch S, Koelzer J, et al. Noninvasive markers in the assessment of intestinal inflammation in IBD: performance of fecal lactoferrin, calprotectin, PMN-elastase, CRP and clinical indices. Am J Gastroenterol 2008; 103: 162-9.

17. Schoepfer AM, Trummler M, Seecholzer P, et al. Discriminating IBD from IBS: comparison of the performance of fecal markers, blood leucocytes, CRP and IBD antibodies. Inflamm Bowel Dis 2008; 14: 32-9.

18. Shine B, Berghouse L, Jones JE, et al. C-reactive protein as an aid in the differentiation of functional and inflammatory bowel disorders. Clin Chim Acta 1985; 148: 105-9.

19. Chamouard P, Richert Z, Meyer N, et al. Diagnostic value of Creactive protein for predicting activity level of Crohn's disease. Clinical Gastroenterol Hepatol 2006; 4: 882-7.

20. Rutgeerts P, Colombel J, Enns R, et al. Subanalysis from a phase 3 study on the evaluation of natalizumab in active Crohn's disease. Gut 2003; 52 (Suppl.): A239.

21. Sandborn WJ, Weagan BG, Radford-Smith G, et al. CDP571, a humanised monoclonal antibody to tumour necrosis factor alpha, for moderate to severe Crohn's disease: a randomised, double blind, placebo controlled trial. Gut 2004; 53: 1485-93.

22. Schreiber S, Rutgeerts P, Fedorak RN, et al. CDP870 Crohn's Disease Study Group. A randomized, placebo-controlled trial of certolizumab pegol (CDP870) for treatment of Crohn's disease. Gastroenterology 2005; 129: 807-18.

23. Szalai AJ, McCrory MA, Cooper GS, et al. Association between baseline levels of C-reactive protein (CRP) and a dinucleotide repeat polymorphism in the intron of the CRP gene. Genes Immun 2002; 3: 14-9.

24. Russell Al, Cunninghame Graham DS, Shepherd C, et al. Polymorphism at the C-reactive protein locus influences gene expression and predisposes to systemic lupus erythematosus. Hum Mol Genet 2004; 13: 137-47.

25. Carlson CS, Aldred SF, Lee PK, et al. Polymorphisms within the C-reactive protein (CRP) promoter region are associated with plasma CRP levels. Am J Hum Genet 2005; 77: 64-77.

26. Willot $\mathrm{S}$, Vermeire $\mathrm{S}$, Ohresser $\mathrm{M}$, et al. C-reactive protein gene polymorphisms are not associated with biological or clinical response to infliximab in Crohn's disease. Gastroenterology 2005; 128 (Suppl.): A311. 
27. Frøslie KF, Jahnsen J, Moum BA, Vatn MH; IBSEN Group. Mucosal healing in inflammatory bowel disease: results from a Norwegian population-based cohort. Gastroenterology 2007; 133: 412-22.

28. Modigliani R. Endoscopic severity index for Crohn's disease. Gastrointest Endosc 1990; 36: 637-44.

29. Sipponen T, Kärkkäinen P, Savilahti E, et al. Correlation of faecal calprotectin and lactoferrin with an endoscopic score for Crohn's disease and histological findings. Aliment Pharmacol Ther 2008; 128: 1221-9.

30. Solem CA, Loftus EV Jr, Tremaine WJ, et al. Correlation of Creactive protein with clinical, endoscopic, histologic, and radiographic activity in inflammatory bowel disease. Inflamm Bowel Dis 2005; 11: 707-12. 